\title{
Endobronchinio ultragarso tyrimo principai
}

\author{
Doc. dr. Marius Žemaitis, doc. dr. Skaidrius Miliauskas, dr. Kristina Stravinskaitė, \\ prof. dr. Raimundas Sakalauskas \\ KMU Pulmonologijos ir imunologijos klinika
}

Reikšminai žodžiai: endobronchinis ultragarsas, bronchoskopija, invazinè pulmonologija.

Santrauka. Endobronchinio ultragarso tyrimas yra naujas ir saugus invazinės pulmonologijos diagnostikos metodas, padedantis gydytojui pulmonologui j̨vertinti kvejpavimo takų sienelės struktūrą ir ją supančius darinius bei atlikti minimaliai invazines diagnostines procedūras kontroliuojant ultragarsu.

Kauno medicinos universiteto Pulmonologijos ir imunologijos klinikoje pirmą kartą Lietuvoje 2009 metų balandžio ménesị atliktos naujo invazinès pulmonologijos tyrimo metodo - endobronchinio ultragarso (angl. endobronchial ultrasound, EBUS) - procedūros, taigi šio straipsnio tikslas - supažindinti su endobronchinio ultragarso tyrimo principais.

\section{ENDOBRONCHINIO ULTRAGARSO TIPAI}

Šiuo metu klinikinèje praktikoje yra taikomi du EBUS tyrimo metodai - naudojant radialinị ir sektorinị ultragarsini daviklius.

Radialiniai ultragarsiniai davikliai klinikinejje praktikoje pradeti naudoti apytikriai 1990 metais kvèpavimo takų sienelès navikinei infiltracijai, vèliau ir tarpuplaučio bei šaknų limfmazgių ir periferiniams dariniams plaučiuose ịvertinti. Maži $20 \mathrm{MHz}$ dažnio ultragarsiniai radialiniai davikliai, distaliniame gale turintys izotoniniu vandeniu išpučiamus balionèlius, kurie pagerina kontaktą tarp ultragarsinio daviklio ir kvėpavimo taku sienelès bei tuo pačiu vaizdą, yra pritaikyti centrinių kvėpavimo takų (iki subsegmentiniu bronchų) ir apie juos esančioms struktūroms vertinti. Labai maži ultragarsiniai radialiniai davikliai kartu su nukreipiamuoju kateteriu yra naudojami periferiniams dariniams plaučiuose diagnozuoti. Abu šie radialiniai ultragarsiniai davikliai yra įleidžiami pro iprastinio fibrobronchoskopo darbini kanalą. $20 \mathrm{MHz}$ dažnio ultragarsinių radialinių daviklių skiriamoji geba yra mažesnè nei $1 \mathrm{~mm}$, ịsiskverbimo gylis $-5 \mathrm{~cm}$, matomas $360^{\circ}$ ultragarsinis vaizdas [1].

Pagrindinis radialinių ultragarsinių daviklių trūkumas - negalejjimas diagnostinių procedūrų atlikti realiu laiku paskatino specialiu ultragarsiniu fibrobronchoskopu su sektoriniais ultragarsiniais davikliais atsiradimą 2002 metais. Sektorinis 7,5 MHz dažnio ultragarsinis daviklis, įmontuotas specialaus ultragarsinio bronchoskopo distaliniame gale, pateikia sektorini (lygiagretų su įleidžiamo bronchoskopo kryptimi) ultragarsini $50^{\circ}$ vaizdą, kai ịsiskverbimo gylis yra $5 \mathrm{~cm}$. Izotoniniu vandeniu pripildomas balionèlis, užmaunamas ant sektorinio ultragarsinio daviklio, pagerina kontaktą su kvėpavimo takais bei vaizdą. Speciali ultragarso kontrastinè adata, ịleidžiama pro darbinį bronchoskopo kanalą, leidžia atlikti diagnostines procedūras realiu laiku kontroliuojant ultragarsu. Viena iš svarbiausių diagnostinių endobronchinio ultragarsinio tyrimo sričių tarpuplaučio limfmazgių diagnostika [2].

Tiek naudojant radialinius, tiek sektorinius ultragarsinius daviklius galimas doplerinis režimas, padedantis ịvertinti kraujagysles bei išvengti komplikacijų punkcinių biopsijų metu [3].

\section{METODIKA}

EBUS procedūros atliekamos ambulatoriniams ar stacionare gydomiems pacientams gydytojo pulmonologo. Pacientas turi galèti atsigulti ant nugaros. Bent savaitę iki numatomos invazinès procedūros reikia nutraukti varfarino ar klopidogrelio vartojimą, o krešèjimo rodikliai turi būti normalūs. Procedūra atliekama sukèlus vietinę nejautrą lidokaino 10 proc. ir 2 proc. tirpalu, o slopinimą - midazolamu pro intravenini kateterị, tiekiant deguoni pro nosinị kateterị, stebint deguonies saturaciją ir širdies susitraukimų dažni pulsoksimetru. Transbronchinès adatinès aspiracinès biopsijos, kontroliuojamos EBUS (angl. endobronchial ultrasound - 
transbronchial needle aspiration, EBUS-TBNA), atliekamos pagal Europos respiratologu sąjungos nuorodas [4]. EBUS-TBNA procedūru metu paimtas mèginys citologiniam tyrimui dedamas ant stikliuko darant tepinèlius ar i̇ citologiniams tyrimams skirtą skystị. Jei méginys dètas i citologiniams tyrimams skirtą skystí, iš šio méginio daromi ląstelių blokai histologiniam tyrimui. Po EBUS-TBNA procedūrų ligonis stebimas mažiausiai vieną valandą, o jei pacientas buvo slopinamas - neleidžiama tą dieną vairuoti ir (ar) valdyti kitų technikos priemonių [5].

\section{INDIKACIJOS ATLIKTI EBUS TYRIMĄ $[4,5,6,7]$}

1. Indikacijos atlikti EBUS tyrimą radialiniais davikliais:

1.1. Ankstyvojo plaučių véžio diagnostika įvertinant naviko infiltracijos i kvėpavimo taku sienelę gylị.

1.2. Plaučių vėžio lokalaus išplitimo ịvertinimas.

1.3. Stemplès bei skydliaukès véžio išplitimo ị kvejpavimo takus įvertinimas.

1.4. Periferinių darinių plaučiuose nustatymas prieš transbronchinę biopsiją.

2. Indikacijos atlikti EBUS tyrimą sektoriniais davikliais:

2.1. Intratorakalinių pokyčių diagnostika:

2.1.1. Centriniai plaučiuc parenchimos pokyčiai, kurių nematyti standartinès fibrobronchos kopijos metu.

2.1.2. Itariamas intratorakalinis ar ekstratorakalinis navikas esant padidejusiems ar pozitronų emisijos tomografijos tyrimo metu nustatytiems pozityviems šaknų ar tarpuplaučio limfmazgiams.

2.1.3. Ittariama granulominè liga ir yra padidèję šaknų ar tarpuplaučio limfmazgiai.

2.1.4. Tarpuplaučio pokyčiai ar masès, kuriems patikslinti reikalingas citologinis ar histologinis tyrimas.

2.2. Nustatytu intratorakaliniu ir ekstratorakaliniuc navikų išplitimo įvertinimas:

2.2.1. Nesmulkiụjų ląstelių plaučių vėžio išplitimo nustatymas.

2.2.2. Žinomas ekstratorakalinis navikas ir yra padidèję ar pozitronų emisijos tomografijos tyrimo metu nustatyti pozityvūs tarpuplaučio ar šaknų limfmazgiai.

2.2.3. Žinomas ekstratorakalinis navikas ir yra centrinių plaučiuc parenchimos pakitimų, kuriems patikslinti reikalingas citologinis ar histologinis tyrimas

\section{KONTRAINDIKACIJOS IR KOMPLIKACIJOS}

Kontraindikacijos atlikti EBUS tyrimą yra tokios pat kaip ir standartinès fibrobronchoskopijos (nekoreguojamas kvejpavimo funkcijos nepakankamumas, gerkluc ar trachejjos stenozè, nekoreguoti krešejjimo sutrikimai ir kt.). EBUS tyrimas yra saugi ir paciento gerai toleruojama procedūra. Taikant vietinę nejautrą ir slopinimą gerai procedūrą toleruota 93,6 proc. tiriamųjų [8]. Komplikacijų (mediastinitas, pneumotoraksas, kraujavimas, hipoksemija) atliekant EBUS-TBNA procedūras pasitaiko labai retai $[9,10,11]$.

\section{IŠVADA}

Endobronchinio ultragarso tyrimas yra naujas invazinès pulmonologijos diagnostikos metodas, padedantis ịvertinti kvėpavimo takų struktūrą ir juos supančius darinius (navikus, limfmazgius, kraujagysles ir kt.) bei atlikti minimaliai invazines diagnostines procedūras kontroliuojant ultragarsu.

\section{ENDOBRONCHIAL ULTRASOUIND DIAGNOSTIC TOOL PRINCIPLES}

\section{MARIUS ŽEMAITIS, SKAIDRIUS MILIAUSKAS, KRISTINA STRAVINSKAITĖ, RAIMUNDAS SAKALAUSKAS \\ DEPARTMENT OF PULMONOLOGY AND IMMUNOLOGY KAUNAS UNIVERSITY OF MEDICINE}

Keywords: endobronchial ultrasouind, bronchoscopy, invasive pulmonology. Summary. Endobronchial ultrasound is a new and safe diagnostic tool that allow to evaluate airway structure and processes surrounding the airway as well as to perform endobronchial ultrasound guided diagnostic procedures.

\section{LITERATŨRA}

1. Falcone F, Fois F, Grosso D. Endobronchial ultrasound. Respiration 2003; 70; 87-94.

2. Herth FJF, Krasnik M, Yasufuku K, Rintoul R, Ernst A. Endobronchial ultrasound-guided transbronchial needle aspiration. J Bronchol 2006; 13: 84-91.

3. Yasufu K, Nakajima T, Chiyo M, Sekine Y, et al. Endobronchial ultrasonography: current status and future directions. J Thorac Oncol 2007; 2: 970979.

4. Herth FJF, Rabe KF, Gasparini S, Annema JT. Transbronchial and transoesophageal (ultrasound-guided) needle aspirations for the analysis of mediastinal lesions. Eur respir J 2006; 28: 1264-1275.

5. Tournoy KG, Dooms C, Bolly A, Galdermans D. EUS-FNA and EBUS-TBNA in pulmonary medicine: consensus report of the belgian working party for thoracic endoscopy.

6. Krimsky W, Sarkar S, Kurimoto N, Musami A. Endobronchial ultrasound: current applications and future directions. J Bronchol 2007; 14: 63-69.

7. Detterbeck FC, Jantz MA, Wallace MB, et al. Invasive mediastinal staging of lung cancer. ACCP evidence based clinical practice guidlines ( 2 nd edition). Chest 2007; 202S-220S

8. Falcone F, Fois F, Patelli M, Grosso D, et al. Feasibility of endobronchial sonography (EBUS): preliminary results in Italiant experience; in Yoshimura $\mathrm{H}$ (ed) Bronchology and bronchoesophagology: State of the art. Oxford, Elservier Science, 2001, pp 905-908.

9. Al-Haddad M, Wallace MB, Woodward TA, et al. The safety of fine-needle aspiration guided by endoscopic ultrasound: a prospective study. Endoscopy 2008; 40: 204-208.

10. Aerts JG, Kloover J, Los J, et al. EUS-FNA of enlarged necrotic lymph nodes may cause infectious mediastinitis. J Thorac Oncol 2008; 3(10): 1191-1193.

11. Tournoy KG, Burgers SA, Annema JT, et al. Transesophageal endoscopic ultrasound with fine needle aspiration in the preoperative staging of malignant pleural mesothelioma. Clin Cancer Res 2008; 14(19): 62596263. 